\title{
DYNAMIC MODEL OF A CLOSED-LOOP HYDRAULIC SYSTEM FOR SPEED CONTROL THROUGH GEAR DIFFERENTIAL
}

\author{
Oleh Strilets $^{1}$; Volodymyr Malashchenko²; Volodymyr Strilets ${ }^{1}$ \\ ${ }^{1}$ National University of Water And Environmental Engineering, Rivne, Ukraine \\ ${ }^{2}$ Lviv Polytechnic National University, Lviv, Ukraine
}

\begin{abstract}
Summary. A mathematical dynamic model of a closed hydraulic system for controlling speed changes through a gear differential, which consists of a motor, a gear transmission, a gear hydraulic pump, a closed-loop pipeline, and a control valve, is obtained. The engine can be a solar gear, or an epicycle, or a gear differential, and with the help of a closed hydraulic system, you can change the speed of the solar gear, or an epicycle, or a carrier from when the gear pump pumps fluid in a closed pipe. when the pipeline is closed by the regulating crane, the gear hydraulic pump will be stopped and the link on which the closed hydraulic system is installed will be stopped. The result is an analytical expression to determine the speed of the fluid in a closed hydraulic system, which depends on the angular velocity of the engine - the control links of the solar gear, or epicycle, or carrier.

Key words: closed-loop hydraulic system, hydraulic gear pump, gear differential, sun gear, ring gear, planet, dynamic model.
\end{abstract}

Statement of the problem. In modern mechanical engineering to control changes in speed of different machines in magnitude and direction, various stepped, stepless and combined gearboxes have been widely described in [1-2]. Known methods and devices for controlling changes in speed have many disadvantages. The main disadvantages of stepped speed control by magnitude and direction are: the complexity of the design of such devices, high material consumption, high dynamic loads that occur during the transition from one speed to another, even with synchronizers. For stepless speed control, the main disadvantage is the intensive operation of the parts due to friction because of the use of friction brakes and locking friction clutches. These shortcomings adversely affect the durability and reliability of drive parts and machines in general. The development at the level of the invention of a moving cargo stopper (RU Pat. No. 2211796 and UA Pat. No. 44135) in the form of a closed hydraulic system and its application in gear differential, allowed to develop at the level of utility models (UA Pat. No. 7328, 11121, 18514, 18587, 28489, 48301, 48608, 108239) new devices for controlling changes in speed due to the fluid moving in a closed-loop hydraulic system. Abovementioned devices eliminate these shortcomings. Extensive kinematic [3-5] and energy [6-9] researches have been carried out for such devices, which have proved the possibility of their application in mechanical drives of machines. This work is devoted to the study of dynamic processes in a closed-loop hydraulic system for speed control through a gear differential.

Analysis of the available investigations. Recent studies and publications on volumetric hydraulic drive with gear hydraulic pumps [10-17] have been considered.

In [10] an experimental study of the flow of hydraulic fluid inside the gear pump have been described, based on its low complexity, high reliability and ease of use, creating a constant fluid flow rate and this computational study is recommended as a method to study fluid flow within different volumes, capacitive models used in the field of industrial hydraulic drive. 
[11] describes the method of HYGESim modeling, external gear pumps that work with non-Newtonian fluids with different viscosity characteristics and describes several comparisons between modeling results and experimental data obtained to verify the presented method.

In [12], elliptical gear hydraulic pumps have been considered, in order to effectively reduce fluid flow fluctuations by means of a variable angular velocity drive, where the influence of eccentric ratio, number of placement order and rotor modulus on flow rate have been analyzed, then external non-circular gear drive has been proposed and finally a prototype pump has been created, which proves that the ripple of the flow can be effectively reduced.

In [13], a three-dimensional numerical simulation of an external gear pump has been performed to study the influence of 3D-geometric design parameters on the pump performance characteristics such as flow rate, internal pressure, local cavitation and supply pressure ripple. The method (ISM) has been used to simulate the operation of the pump in extreme conditions with high speed. It has been found that the maximum flow rate of the gear pump is a function of the clearance of the gear tip and the side clearance and with the help of a 3D model highlights the effect of the side clearance on the flow rate.

[14] has proposed a systematic procedure for determining the variable excitation loads that occur due to changes in the pressure inside the gear spaces in the external gear pumps. A general methodology for determining the pressure force and torque components along three coordinate axes has been suggested. The pressures under this procedure have been compared with other methods and showed that this methodology is able to describe a wider range of phenomena involved in determining all components of pressure and torque.

In [15] the problem of determining the relative performance of spur and helical external gear pumps (EGP) for fluid energy transfer has been considered. This includes solving two main tasks, parameterizing the overall design of the EGP and quantifying its effectiveness. Using this procedure, the genetic algorithm can continue to improve from generation to generation until the optimal set of designs is determined, both for oblique and for straighttoothed units.

In [16]-[18] the reliability of the use of gear hydraulic pumps in speed change devices by means of gear differentials with closed-loop hydraulic systems has been substantiated, when the control link is a sun gear, or an ring gear, or a carrier.

An analysis of recent publications shows that scientific work associated with the use of volumetric hydraulic drives with gear pumps are barely associated with closed-loop hydraulic systems.

The objective of the work. Development of a dynamic model of a closed-loop hydraulic system with gear hydraulic pumps to control speed changes through the gear differential of mechanical drives of machines.

Realization of the work. Figure 1 shows a scheme of a closed-loop hydraulic system (hydraulic stopper) for controlling speed changes through a gear differential, which consists of a gear hydraulic pump 1, pipes 2 , control valve 3 , check valve 4 and a tank for fluid 5.

A closed-loop hydraulic system works as follows. The gear hydraulic pump pumps the fluid in a closed-loop hydraulic system when the control valve is open. If the control valve is closed, the gear hydraulic pump is stopped and, at the same time, the link on which the closedloop hydraulic system is installed is stopped. This principle of operation of a closed-loop hydraulic system is used to control changes in the speed of the driven link of the gear differential depending on the speeds of the driving link and the control link.

The control link can be a sun gear, or an ring gear, or a carrier of gear differential, and depending on the capacity of the fluid moving through the pipeline of a closed-loop hydraulic system, the angular velocity of the control link $\omega_{\mathrm{c}}$ varies from 0 to $\omega_{\mathrm{c} \text { max }}$ or vice versa, leading and subordinate links. This has been confirmed by kinematic studies [3-5] and others. 


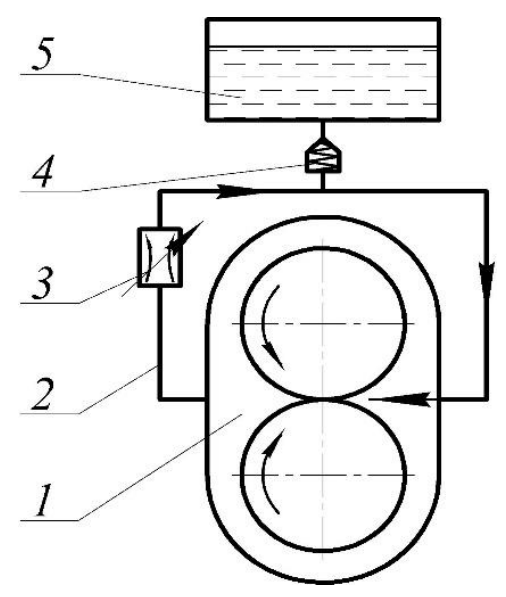

Figure 1. Scheme of a closed-loop hydraulic system for controlling speed changes in a gear differential

To study the dynamic processes in the hydraulic stopper (closed-loop hydraulic system) to control speed changes through the gear differential, we present it in the form of a structural scheme shown in Figure 2. The engine «M» in the scheme is a control link 1 of a gear differential - either sun gear, or an ring gear, or the carrier connected to the gear hydraulic pump 2 of the closed-loop hydraulic system by a gear transmission $\left(z_{1}\right.$ and $\left.z_{2}\right)$ and can pump liquid, on the pipeline 3 when the control valve is open. The gearing can be with a gear ratio $u_{12}=\omega_{1} / \omega_{2}=z_{2} / z_{1}$, where $u_{12}>1$ either $u_{12}<1$, and $\omega_{1}=\omega_{M}$ is the speed of the control link $« \mathrm{M} »-$ the sun gear, or ring gear, or carrier.
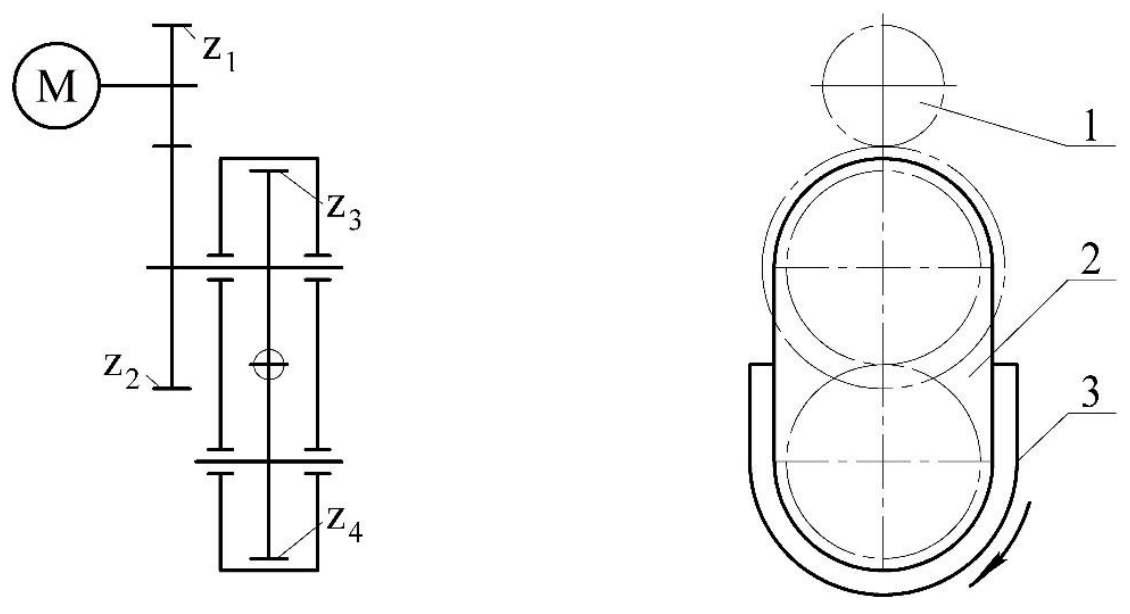

Figure 2. Scheme of the drive of the hydraulic stopper for speed changes control in a gear differential

We model the motion of a mechanical system in a formalized form, using the Lagrange equation of the second kind

$$
\frac{d}{d t}\left(\frac{\partial T}{\partial \omega}\right)=\Sigma M_{i}
$$

To do this, write the expression for the kinetic energy of the system shown in Figure 2.

$$
T=\frac{1}{2}\left(J_{M} \omega_{M}^{2}+J_{z 1} \omega_{z 1}^{2}+J_{z 2} \omega_{z 2}^{2}+J_{z 3} \omega_{z 3}^{2}+J_{z 4} \omega_{z 4}^{2}+m v^{2}\right)
$$


where $J_{M}, J_{z 1}, J_{z 2}, J_{z 3}$ i $J_{z 4}$-dynamic moments of inertia, respectively, of the engine, which may be a sun gear, or ring gear, or carrier, gears $z_{1}, z_{2}, z_{3}$ and $z_{4}$ with shafts; $m$ - is the mass of the fluid in the closed-loop hydraulic system (in the gear hydraulic pump 2 and the pipeline 3, see Figure 2); $\omega_{M}, \omega_{z 1} \omega_{z 2}, \omega_{z 3} \mathrm{i} \omega_{z 4}$ - angular velocities of the engine, gears $z_{1}, z_{2}, z_{3}$ and $z_{4}$, respectively; $v$ - is the velocity of the liquid in the pipeline.

Let's express the meaning $\omega_{z 1} ; \omega_{z 2} ; \omega_{z 3} ; \omega_{z 4}$ by the value of $\omega_{M}$. From the scheme of the hydraulic stopper drive for speed changes control in a gear differential (Figure 2 see) it is obvious that $\omega_{z 1}=\omega_{M} ; \omega_{z 2}=\omega_{M} / u_{12} ; \omega_{z 3}=\omega_{z 4}=\omega_{z 2}$, where $u_{12}=\omega_{M} / \omega_{z 2}$, or $u_{12}=z_{2} / z_{1}$. By substituting these values into expression (2) and group we get

$$
T=\frac{1}{2}\left[\left(J_{M}+J_{z 1}\right) \omega_{M}^{2}+\left(J_{z 2}+J_{z 3}+J_{z 4}\right)\left(\omega_{M} / u_{12}\right)^{2}+m v^{2}\right]
$$

or

$$
2 T=\left(J_{M}+J_{z 1}\right) \omega_{M}^{2}+\left(J_{z 2}+J_{z 3}+J_{z 4}\right)\left(\omega_{M} / u_{12}\right)^{2}+m v^{2}
$$

The mass of the liquid in the closed-loop hydraulic system and its speed during pumping are determined from the expressions:

$$
m=\left(\frac{\pi d_{y}^{2}}{4} L+q\right) \gamma, v=\frac{4 q \omega_{M}}{\pi d_{y}^{2} u_{12}} .
$$

In these formulas we have: $L$ - length and $d_{y}$ - diameter of the conditional passage of the pipeline of the closed-loop hydraulic system; $\gamma$ is the specific weight of the liquid and $q$ is the flow rate of the hydraulic pump per single revolution (volume of the hydraulic pump).

Substitute the values of $v$ and $m$ in (4) and group, we have:

$$
2 T=\left[\left(J_{M}+J_{z 1}\right) u_{12}^{2}+\left(J_{z 2}+J_{z 3}+J_{z 4}\right)+\frac{4 q^{2} \gamma}{\pi d_{y}^{2}}\left(L+\frac{4 q}{\pi d_{y}^{2}}\right)\right]\left(\omega_{M} / u_{12}\right)^{2} .
$$

Then

$$
\frac{\partial T}{\partial \omega_{M}}=\frac{\left[\left(J_{M}+J_{z 1}\right) u_{12}^{2}+\left(J_{z 2}+J_{z 3}+J_{z 4}\right)+\frac{4 q^{2} \gamma}{\pi d_{y}^{2}}\left(L+\frac{4 q}{\pi d_{y}^{2}}\right)\right] \omega_{M}}{u_{12}^{2}},
$$

and

$$
\frac{d}{d t}\left(\frac{\partial T}{\partial \omega_{M}}\right)=\frac{\left[\left(J_{M}+J_{z 1}\right) u_{12}^{2}+\left(J_{z 2}+J_{z 3}+J_{z 4}\right)+\frac{4 q^{2} \gamma}{\pi d_{y}^{2}}\left(L+\frac{4 q}{\pi d_{y}^{2}}\right)\right] \omega_{M}^{\prime}}{u_{12}^{2}} .
$$

Finally we have the equation

$$
\frac{\left[\left(J_{M}+J_{z 1}\right) u_{12}^{2}+\left(J_{z 2}+J_{z 3}+J_{z 4}\right)+\frac{4 q^{2} \gamma}{\pi d_{y}^{2}}\left(L+\frac{4 q}{\pi d_{y}^{2}}\right)\right] \omega_{M}^{\prime}}{u_{12}^{2}}=M_{f o},
$$


where $M_{f o}$ - the moment created in the hydraulic pump by the liquid, which is found from the power of the hydraulic system.

$$
\Sigma M_{i}=M_{f o}=\frac{P}{\omega_{z 3}}
$$

where $P$-hydraulic system power; $\omega_{z 3}$ - angular speed of a gear wheel of the hydraulic pump.

Hydraulic system power

$$
P=\frac{p Q}{u_{12}}
$$

where $p$ - the pressure of the fluid moving in the pipeline and $Q$ - the flow rate of the hydraulic pump.

$$
M_{f o}=\frac{p Q}{\omega_{\partial}}
$$

Substituting the value of (12) in (2) we obtain the differential equation

$$
\frac{\left[\left(J_{M}+J_{z 1}\right) u_{12}^{2}+\left(J_{z 2}+J_{z 3}+J_{z 4}\right)+\frac{4 q^{2} \gamma}{\pi d_{y}^{2}}\left(L+\frac{4 q}{\pi d_{y}^{2}}\right)\right] \omega_{M}^{\prime}}{u_{12}^{2}}-\frac{p Q}{\omega_{M}}=0
$$

or

$$
A \omega_{M}^{\prime}-\frac{B}{\omega_{M}}=0
$$

where

$$
A=\frac{\left[\left(J_{M}+J_{z 1}\right) u_{12}^{2}+\left(J_{z 2}+J_{z 3}+J_{z 4}\right)+\frac{4 q^{2} \gamma}{\pi d_{y}^{2}}\left(L+\frac{4 q}{\pi d_{y}^{2}}\right)\right]}{u_{12}^{2}} ; B=p Q .
$$

In differential equation (14) we divide the variables, integrate and obtain:

$$
A \omega_{M} d \omega_{M}=B d t ; A \int \omega_{M} d \omega_{M}=B \int d t ; A \omega_{M}^{2} / 2=B t+C
$$

Since we have enough of any nonzero solution of equation (14), we accept $C=0$, then

$$
\omega_{M}^{2}=2 B t / A
$$

or

$$
\omega_{M}= \pm \sqrt{2 B t / A}
$$


Let's return to the initial symbols, finally we have

$$
\omega_{M}= \pm \sqrt{\frac{2 p Q u_{12}^{2} t}{\left(J_{M}+J_{z 1}\right) u_{12}^{2}+\left(J_{z 2}+J_{z 3}+J_{z 4}\right)+\frac{4 q^{2} \gamma}{\pi d_{y}^{2}}\left(L+\frac{4 q}{\pi d_{y}^{2}}\right)}} .
$$

Thus, a mathematical dynamic model of the motion of a closed-loop hydraulic system for the speed change control through a gear differential and a link, which can be either a sun gear, or an ring gear, or a carrier, has been successfully developed in this work.

Conclusions. A mathematical dynamic model of a closed-loop hydraulic system for a gear differential has been constructed, which according to the required speed makes it possible to select a gear hydraulic pump to control the speed of its driven link. The obtained results can be the basis for a quantitative analysis of the kinematic and force dependences of the mechanical drive with hydraulic control.

\section{References}

1. Malashchenko V. O., Strilets O. R., Strilets V. M. Klasyfikatsiya sposobiv i prystroyiv keruvannya protsesom zminy shvydkosti u tekhnitsi. Pidyomno-transportna tekhnika. Odesa: ONPU, 2015. No. 1. P. 70-78. [In Ukrainian].

2. Malashchenko V., Strilets O., Strilets V. Fundamentals of Creation of New Devices for Speed Change Management. Ukrainian Journal of Mechanical Engineering and Materials Science. Lviv, 2015. Vol. 1. No. 2. P. 11-20.

3. Strilets O. R. Keruvannya zminamy shvydkosti za dopomohoyu dyferentsialnoyi peredachi cherez epitsykl. Visnyk Ternopilskoho natsionalnoho tekhnichnoho universytetu. Ternopil: TNTU, 2015. No. 4 (80). P. 129-135. [In Ukrainian].

4. Strilets O. R. Keruvannya protsesom zminy shvydkosti za dopomohoyu dyferentsialnoyi peredachi cherez sonyachne zubchaste koleso. Visnyk Khmelnytskoho natsionalnoho universytetu. Tekhnichni nauky. Khmelnytskyy: KhNU, 2015. No. 5 (229). P. 68-72. [In Ukrainian].

5. Strilets O. R. Keruvannya protsesom zminy shvydkosti za dopomohoyu dyferentsialnoyi peredachi cherez vodylo. Visnyk Kremenchutskoho natsionalnoho universytetu. Kremenchuk: KrNU, 2015. Iss. 6 (95). P. 72-77. [In Ukrainian].

6. Strilets O. R. The efficiency of the differential gear to devices for controlling the speed change through a sun gear. Odes'kyi Politechnichnyi Universytet. Pratsi, Issue 2 (52), 2017. P. 29-38. https://doi.org/10.15276/opu.2.52.2017.05

7. Malashchenko, V., Strilets, O., \& Strilets, V. Determining performance efficiency of the differential in a device for speed change through ring gear. Eastern-European Journal of Enterprise Technologies, 2017, 6 (7 (90)), P. 51-57. https://doi.org/10.15587/1729-4061.2017.110683.

8. Malashchenko V., Strilets O., Strilets V., Klysz S. Investigation of the energy effectiveness of multistage differential gears when the speed is changed by the carrier. Diagnostyka. Warchava, 2019. Vol. 20. No. 6. P. 57-64. https://doi.org/10.29354/diag/112397

9. Strilets O. R., Malashchenko V. O., Strilets V. M. Energy effectiveness of the differential of a device for speed change through the sun gear. Naukovyi Visnyk Natsionalnoho Hirnychoho Universytetu. Dnipro: NHU, 2019. No. 6. P. 52-57. https://doi.org/10.29202/nvngu/2019-6/10

10. Scheaua Fănel. The Use Of Numerical Analysis In Order To Highlight The Fluid Dynamics Inside A Hydraulic Gear Pump Model. Journal of Industrial Design and Engineering Graphics. 2015. 10 (3). P. 33-36.

11. Rituraj, F., Vacca, A. (2018) External gear pumps operating with non-Newtonian fluids: Modelling and experimental validation. Mech. Syst. Signal Process. 106, P. 284-302. https://doi.org/10.1016/ j.ymssp.2017.12.042

12. Dawei Liu, Yanbo Ba, Tingzhi Ren (2019) Flow fluctuation abatement of high-order elliptical gear pump by external noncircular gear drive. Mechanism Theory, 134, P. 338-348. https://doi.org/10.1016/ j.mechmachtheory.2019.01.011

13. Yonghan Yoon, Byung-Ho Park, Jaesool Shim, Yong-Oun Han, Byeong-Joo Hong, Song-Hyun Yun, (2017) Numerical simulation of three-dimensional external gear pump using immersed solid method. Applied Thermal Engineering, 118, P. 539-550. https://doi.org/10.1016/j.applthermaleng.2017.03.014

14. Battarra, M., Mucchi, E., A method for variable pressure load estimation in spur and helical gear pumps. Mechanical Systems and Signal Processing. 76-77, P. 265-282. https://doi.org/10.1016/j.ymssp. 2016.02.020 
15. A. Ransegnola, T., Zhao, X., Vacca, A., (2019) A comparison of helical and spur external gear machines for fluid power applications: Design and optimization. Mechanism and Machine Theory, 142, 103604. https://doi.org/10.1016/j.mechmachtheory.2019.103604

16. Strilets O. R., Malashchenko V. O., Strilets V. M. Otsinka nadiynosti prystroyiv keruvannya zminamy shvydkosti cherez zubchasti dyferentsialy na osnovi yikh enerhetychnoyi efektyvnosti. Naukovyy zhurnal "Tekhnichnyy servis ahropromyslovoho, lisovoho ta transportnoho kompleksiv". Kharkiv: KhNTUSH, 2018. No. 13. P. 147-154. [In Ukrainian].

17. Malashchenko V. O., Strilets O. R., Strilets V. M. Otsenka energeticheskoy effektivnosti zubchatykh differentsialov ustroystv upravleniya skorostyu opredeleniyem koeffitsiyenta poleznogo deystviya. Sbornik trudov 4-go Moskovskogo Mezhdunarodnogo simpoziuma "Privodnaya tekhnika i komponenty mashin". M.: ROSPTO - IMASH RAN, 2018. P. 36-41. [In Russian].

18. Strilets O. R., Malashchenko V. O., Strilets V. M. Obgruntuvannya budovy i pryntsypu roboty zupynnyka dlya lanky keruvannya shvydkistyu zubchastoho dyferentsiala. Visnyk Natsional'noho tekhnichnoho universytetu "KHPI". Zbirnyk naukovykh prats'. Seriya: Mashynoznavstvo ta SAPR. Kharkiv: NTU “KhPI”, 2018. No. 25 (1301). P. 89-92. [In Ukrainian]. https://doi.org/10.20998/2079-0775.2018.25.17

\section{Список використаної літератури}

1. Малащенко В. О., Стрілець О. Р., Стрілець В. М. Класифікація способів і пристроїв керування процесом зміни швидкості у техніці. Підйомно-транспортна техніка. Одеса: ОНПУ, 2015. № 1. C. 70-78.

2. Malashchenko V., Strilets O., Strilets V. Fundamentals of Creation of New Devices for Speed Change Management. Ukrainian Journal of Mechanical Engineering and Materials Science. 2015. Vol. 1. No. 2. P. 11-20.

3. Стрілець О.Р. Керування змінами швидкості за допомогою диференціальної передачі через епіцикл. Вісник Тернопільського національного технічного університету. 2015. № 4 (80). С. 129135.

4. Стрілець О. Р. Керування процесом зміни швидкості за допомогою диференціальної передачі через сонячне зубчасте колесо. Вісник Хмельницького національного університету. Технічні науки. 2015. № 5 (229). С. 68-72.

5. Стрілець О. Р. Керування процесом зміни швидкості за допомогою диференціальної передачі через водило. Вісник Кременчуцького національного університету. 2015. Вип. 6 (95). С. $72-77$.

6. Strilets O. R. The efficiency of the differential gear to devices for controlling the speed change through a sun gear. Odes'kyi Politechnichnyi Universytet. Pratsi, Issue 2 (52), $2017 . \quad$ P. 29-38. https://doi.org/10.15276/opu.2.52.2017.05

7. Malashchenko V., Strilets O., \& Strilets V. Determining performance efficiency of the differential in a device for speed change through ring gear. Eastern-European Journal of Enterprise Technologies. 2017. No. 6 (7 (90)). P. 51-57. https://doi.org/10.15587/1729-4061.2017.110683.

8. Malashchenko V., Strilets O., Strilets V., Klysz S. Investigation of the energy effectiveness of multistage differential gears when the speed is changed by the carrier. Diagnostyka. Warchava. 2019. Vol. 20. No. 6. P. 57-64. https://doi.org/10.29354/diag/112397

9. Strilets O. R., Malashchenko V. O., Strilets V. M. Energy effectiveness of the differential of a device for speed change through the sun gear. Naukovyi Visnyk Natsionalnoho Hirnychoho Universytetu. 2019. № 6. P. 52-57. https://doi.org/10.29202/nvngu/2019-6/10

10. Scheaua Fănel. The Use Of Numerical Analysis In Order To Highlight The Fluid Dynamics Inside A Hydraulic Gear Pump Model. Journal of Industrial Design and Engineering Graphics. 2015. 10 (3). P. 3336.

11. Rituraj F., Vacca A. External gear pumps operating with non-Newtonian fluids: Modelling and experimental validation. Mech. Syst. Signal Process. 2018. 106. P. 284-302. https://doi.org/10.1016/ j.ymssp.2017.12.042

12. Dawei Liu, Yanbo Ba, Tingzhi Ren Flow fluctuation abatement of high-order elliptical gear pump by external noncircular gear drive. Mechanism Theory. 2019. 134. P. 338-348. https://doi.org/10.1016/ j.mechmachtheory.2019.01.011

13. Yonghan Yoon, Byung-Ho Park, Jaesool Shim, Yong-Oun Han, Byeong-Joo Hong, Song-Hyun Yun Numerical simulation of three-dimensional external gear pump using immersed solid method. Applied Thermal Engineering. 2017. 118. P. 539-550. https://doi.org/10.1016/j.applthermaleng.2017.03.014

14. Battarra M., Mucchi E., A method for variable pressure load estimation in spur and helical gear pumps. Mechanical Systems and Signal Processing. 76-77. P. 265-282. https://doi.org/10.1016/j.ymssp. 2016.02.020

15. A. Ransegnola, T., Zhao, X., Vacca, A., A comparison of helical and spur external gear machines for fluid power applications: Design and optimization. Mechanism and Machine Theory, 2019, 142, 103604. https://doi.org/10.1016/j.mechmachtheory.2019.103604 
16. Стрілець О. Р., Малащенко В. О., Стрілець В. М. Оцінка надійності пристроїв керування змінами швидкості через зубчасті диференціали на основі їх енергетичної ефективності. Науковий журнал «Технічний сервіс агропромислового, лісового та транспортного комплексів». 2018. № 13. С. 147154.

17. Малащенко В. А., Стрилец О. Р., Стрелец В. Н. Оценка энергетической эффективности зубчатых дифференциалов устройств управления скоростью определением коэффициента полезного действия. Сборник трудов 4-го Московского Международного симпозиума «Приводная техника и компоненты машин». М.: РОСПТО - ИМАШ РАН, 2018. С. 36-41.

18. Стрілець О. Р., Малащенко В. О., Стрілець В. М. Обгрунтування будови і принципу роботи зупинника для ланки керування швидкістю зубчастого диференціала. Вісник Національного технічного університету «ХПІ». Збірник наукових праць. Серія: Машинознавство та САПР. 2018. № 25 (1301). C. 89-92. https://doi.org/10.20998/2079-0775.2018.25.17

\title{
УДК 621.833.65
}

\section{ДИНАМІЧНА МОДЕЛЬ ЗАМКНУТОЇ ГІДРОСИСТЕМИ ДЛЯ КЕРУВАННЯ ШВИДКІСТЮ ЧЕРЕЗ ЗУБЧАСТИЙ ДИФЕРЕНЦІАЛ}

\section{Олег Стрілець ${ }^{1}$ Володимир Малащенко루 Володимир Стрілець ${ }^{1}$}

\author{
${ }^{1}$ Наиіональний університет водного господарства та \\ природокористування, Рівне, Украӥна \\ ${ }^{2}$ Національний університет «Львівська політехніка», Львів, Україна
}

Резюме. В сучасному машинобудуванні для керування змінами швидкості різних машин використовуються ступінчасті ц̆ безступінчасті коробки швидкостей. Відомі пристрої керування змінами швидкості мають багато недоліків, які негативно впливають на довговічність $і$ надійність деталей приводів і машин у цілому. Розроблення на рівні винаходів вантажоупорного зупинника у вигляді замкнутої гідросистеми (пат. № 2211796 RU i nam. № 44135 UA) й застосування його у зубчастих диференціалах дозволило розробити ряд пристроїв для керування змінами швидкості у механічних приводах за рахунок регулювання руху рідини в замкнутій гідросистемі. Це пов 'язано з тим, щзо зубчастий диференціал володіє двома ступенями вільності й у передавання руху приймає три ланки - сонячне зубчасте колесо, епіцикл та водило. Запропоновано, щоб одну із ланок використовувати для керування процесом зміни швидкості між ведучою і веденою ланками за допомогою замкнутої гідросистеми. Розроблені на рівні корисних моделей ряд нових пристроїв керування змінами швидкості підвищують роботоздатність техніки, що підтверджують проведені теоретично-комп'ютерні кінематичні та енергетичні дослідження. Розглянуті останні дослідження й публікації присвячені об'ємному гідроприводу з шестеренчастими гідронасосами. Аналізуючи їх бачимо, щзо наукові роботи, пов'язані з застосуванням об'ємних гідроприводів із шестеренчастими насосами, мало пов'язані з замкнутими гідросистемами. Метою даної роботи є отримання математичної динамічної моделі замкнутої гідросистеми для керування змінами швидкості через зубчастий диференціал, яка складається з двигуна, зубчастої передачі, шестеренчастого гідронасоса, замкнутого трубопроводу й регулювального крана. Двигуном може бути сонячне зубчасте колесо чи епіцикл, або водило зубчастого диференціала. За допомогою замкнутої гідросистеми можна змінювати швидкість сонячного зубчастого колеса або епіцикла, або водила від $\omega_{M}=\omega_{\max }$, коли шестеренчастий гідронасос перекачує рідину в замкнутій гідросистемі у вигляді трубопроводу, коли трубопровід відкритий. А коли трубопровід закритий регулювальним краном, шестеренчастий гідронасос буде зупинений і ланка, на якій встановлена замкнута гідросистема, буде зупинена $\omega_{м}=0$. Для досягнення мети рух механічної системи у формалізованому вигляді змодельовано рівнянням Лагранжа II роду. Для цього складено вирази для кінетичної енергії й обертального моменту та отримано диференціальне рівняння, яке виражає математичну динамічну модель замкнутої гідросистеми. Отримані результати можуть бути підгрунтям для проведення кількісного аналізу кінематичних та силових залежностей механічного привода з гідросистемним керуванням.

Ключові слова: замкнута гідросистема, шестеренчастий гідронасос, зубчастий диференціал, сонячне зубчасте колесо, епіцикл, водило, динамічна модель. 